Supplement of Hydrol. Earth Syst. Sci. Discuss., 12, 1729-1764, 2015

http://www.hydrol-earth-syst-sci-discuss.net/12/1729/2015/

doi:10.5194/hessd-12-1729-2015-supplement

(C) Author(s) 2015. CC Attribution 3.0 License.

(c) (i)

\title{
Temporal parameter sensitivity guided verification of process dynamics
}

M. Pfannerstill et al.

Correspondence to: M. Pfannerstill (mpfannerstill@hydrology.uni-kiel.de) 


\section{Supplement: The original groundwater module of the SWAT model}

The detailed process equations of the groundwater processes for the original SWAT model are summarized in Neitsch et al. (2011). In the following description, the main groundwater processes of the original SWAT version are shown. For this, we focus on the equations that control the groundwater contribution to the discharge of the river.

In the SWAT model, soil water percolates into a conceptual aquifer structure, which is divided into a shallow and a deep aquifer. The shallow aquifer represents an unconfined aquifer that may discharge into the channel. The deep aquifer is described as a confined aquifer. As a consequence, the deep aquifer does not contribute to the streamflow within the watershed. Thus, the deep aquifer is considered as inactive, because it does not deliver water back to the modeled catchment.

Water that percolates out of the soil is delayed with an exponential delay function before it recharges $\left(w_{r c h r g, i} \mathrm{~mm} \mathrm{H}_{2} \mathrm{O}\right)$ the groundwater system (Eq. 1, cf. Neitsch et al. 2011):

$$
w_{r c h r g, i}=\left(1-\exp \left[\frac{-1}{\delta_{g w}}\right]\right) \cdot w_{\text {seep }}+\exp \left[\frac{-1}{\delta_{g w}}\right] \cdot w_{r c h r g, i-1}
$$

The parameter $\delta_{g w}$ (days) describes the delay of recharge that accounts for geologic formations. Eq. 1 considers the percolation out of the last soil layer on day $i\left(w_{\text {seep }}, \mathrm{mm} \mathrm{H}_{2} \mathrm{O}\right)$ and the parameter $w_{\text {rchrg,i-1 }}\left(\mathrm{mm} \mathrm{H}_{2} \mathrm{O}\right)$ which represents

*mpfannerstill@hydrology.uni-kiel.de 
the amount of water that enters the aquifer on the day before $(i-1)$.

With Eq. 2 (cf. Neitsch et al. 2011), the daily recharge $w_{r c h r g, i}$ is partitioned by a percolation coefficient $\beta_{d p}$ (-) to calculate the recharge of the deep aquifer $\left(w_{\text {seep }, d p, i}, \mathrm{~mm}_{2} \mathrm{O}\right)$ :

$$
w_{\text {seep }, d p, i}=\beta_{d p} \cdot w_{\text {rchrg }, i}
$$

The remaining amount of recharge $\left(w_{\text {rchrg,sh }, i}, \mathrm{~mm} \mathrm{H}_{2} \mathrm{O}\right)$ that enters the shallow aquifer is then calculated with Eq. 3 (cf. Neitsch et al. 2011):

$$
w_{\text {rchrg,sh }, i}=w_{\text {rchrg, } i}-w_{\text {seep }, d p, i}
$$

In the SWAT model, groundwater contribution to the river $\left(Q_{g w, i}, \mathrm{~mm}_{2} \mathrm{O}\right)$ is simulated with the shallow aquifer (Eq. 4. cf. Neitsch et al. (2011)). The recharge of the shallow aquifer $\left(w_{r c h r g, s h, i}\right)$ is used together with the parameter $\alpha_{g w}$ (1/days) and a one day time step $(\Delta t)$ to describe a recession-based outflow out of the aquifer storage.

$$
\left.Q_{g w, i}=Q_{g w, i-1} \cdot \exp \left[-\alpha_{g w} \cdot \Delta t\right]\right)+w_{r c h r g, s h, i} \cdot\left(1-\exp \left[-\alpha_{g w} \cdot \Delta t\right]\right)
$$

\section{References}

Neitsch, S. L., Arnold, J. G., Kiniry, J. R., and Williams, J. R.: SWAT Theoretical Documentation Version 2009, Grassland, Soil and Water Research Laboratory, Agricultural Research Service. Blackland Research Center, Texas Agricultural Experiment Station, 2011. 